\title{
A tribute to Flohn (1963): On the meteorological interpretation of Pleistocene climate variations
}

\section{Ulrich Cubasch}

Department of Earth Science, Institute of Meteorology, Freie Universität Berlin, Carl-Heinrich-Becker-Weg 6-10, 12165 Berlin, Germany

Correspondence: $\quad$ Ulrich Cubasch (cubasch@zedat.fu-berlin.de)

Relevant dates: $\quad$ Received: 25 May 2021 - Accepted: 30 October 2021 - Published: 17 December 2021

How to cite: $\quad$ Cubasch, U.: A tribute to Flohn (1963): On the meteorological interpretation of Pleistocene climate variations, E\&G Quaternary Sci. J., 70, 225-227, https://doi.org/10.5194/egqsj-70-225-2021, 2021.

Special issue statement. This article is part of a special issue published on the occasion of the 70th anniversary of $E \& G$ Quaternary Science Journal (EGQSJ). The special issue celebrates the journal's notable contribution to Quaternary research by revisiting selected milestone articles published in the long history of EGQSJ. The German Quaternary Association (DEUQUA) presents translations of the originals and critical appraisals of their impact in tandem anniversary issues of DEUQUASP and EGQSJ, respectively.

Original article: https://doi.org/10.3285/eg.14.1.17

Translation: https://doi.org/10.5194/deuquasp-361-2021

\section{Context}

Hermann Flohn's (1963) publication "On the meteorological interpretation of Pleistocene climate variations" discusses from the perspective of atmospheric sciences the state of knowledge of the Pleistocene climate, which in 1963 was mainly based on geological and geomorphological evidence. It interprets the Pleistocene cold and warm periods and the regionally detectable variations between wet and dry episodes via changes in the large-scale meteorological flow pattern. Flohn identifies gaps and inconsistencies in the prevailing explanations and expresses the hope that with improved methods, in particular enhanced age determination and derivation of paleotemperatures, the Pleistocene climate, which as he states "has been determined by the rampant phantasies of some popular authors" ("ungezügelten Phantasie populärer Autoren"), will be in the future "realistically and physically consistently described using numerical model calculations" ("mit rationalen, physikalischmathematisch fundierten Erwägungen und Modellrechnungen"). Flohn's paper was published in "Eiszeitalter und Gegenwart", and many of the references he cited are found in Quaternary science or geological journals. In 1963, research in paleoclimate changes and their meteorological interpretation was predominantly based on the proxy data of Quaternary sciences, and this topic had hardly entered the recognition of the meteorological community. In those days, meteorologists saw climate research as a necessary but unchallenging byproduct of their routine data collection. Flohn's paper presents the vision that meteorological modeling and Quaternary sciences will have an interdependence in the future. Triggered by the discussion about the influence of mankind on climate, from 1985 onwards the interdisciplinary research into the paleoclimate has been intensifying. The central question was and still is as follows: is the currently experienced global warming of anthropogenic origin (mainly by raising the concentration of greenhouse gases in the atmosphere) or does it stem from natural causes like changes in solar intensity, changes in the orbital parameters, or by the aerosols emitted during volcanic eruptions? In an ongoing international effort, ice and sediment cores have been collected, dated, and interpreted. Data representing the oceanic and atmospheric circulation have been sampled using in situ and 
satellite sources. Numerous numerical models have been developed which simulate the ocean, the atmosphere, the hydrosphere, and the biosphere and their interactions with each other. The effort is coordinated in various national, European, and international programs (WCRP, IGPB, PAGES, IODP). The results are summarized on a quasi-regular basis in the reports of the IPCC (https://www.ipcc.ch, last access: 6 December 2021). It has to be stressed that the current research on the atmospheric paleoclimate focuses on the Holocene due to the data availability and restrictions in the computing resources; the earlier periods of the Pleistocene climate are still being interpreted on the basis of geological evidence.

\section{How has our current knowledge changed compared to that presented by Flohn in 1963?}

At the beginning, Flohn's paper discusses the interaction of the meteorological flow regimes with the glaciation of the Northern Hemisphere, as well as the contribution of these flow regimes to the buildup of the glaciers and their the melting. The general assumption in 1963 was that during the glacials and interglacials the jet stream moves south- and northwards, respectively. The climate zones are shifted synchronously with the glaciation events, linked with a shift of pluvials. However, as Flohn pointed out, geological evidence indicates that this is not consistently the case. He raises the question of whether these inconsistencies are caused by uncertainties in the age determination or if a mechanism has been overlooked that causes regional pluvials to develop independently from the glaciation state. Nowadays changes in the large-scale precipitation pattern are attributed mainly to a shift in the Intertropical Convergence Zone (ITCZ), which follows the changes in the solar insolation induced by variations in the orbital parameters (Milankovic-cycles; Berger, 1978). These insolation changes are also seen as the main driver leading to glaciations (Kaspar and Cubasch, 2007; Wanner et al., 2008). The mechanisms Flohn had found missing are feedback processes, which according to current knowledge influence the formation of a regional wet climate. One feedback mechanism that has been known for a long time in agricultural meteorology consists of the feedback loop in which enhanced precipitation leads to more vegetation, which in turn reinforces the evaporation, which then leads to more precipitation. Its importance for the large-scale climate, however, was only discovered more than 30 years later by Claussen et al. (1999). He proved in model experiments that the vegetation cover of the Sahara is strongly dependent on this vegetation feedback. Flohn assumes that during some of the interglacials the Arctic was free of sea ice. He deduces that this reduces the meridional temperature gradient in the Northern Hemisphere and that this would lead to a stronger meridionalization of the airflow. This assumption is still followed today: with enhanced global warming, the Arctic ice cover is dwindling in the present. The IPCC projec- tions for the high climate change scenarios indicate that the Arctic ice will almost completely disappear within the next 100 years (IPCC, 2013). It has been found by Francis und Vavrus (2015) that already now the decrease in the Arctic ice coverage leads to a diminished Equator-North pole temperature contrast, which induces a wavier jet stream. Flohn calculated that the changes in the radiative balance alone would not have been effective enough for the glacier melt and deduced that during the late- and post-glacials, the changes in the large-scale circulation must have enhanced the advection of warm air. He estimated that, in general, the available heat within the climate system is sufficient to explain the melting of the glaciers and the induced sea level rise. At a first glance, it is a bit surprising that Flohn focused on the atmospheric circulation and does not mention at all the contribution of the heat advection by oceanic currents. However, if one takes the standard German textbook on Oceanography (Dietrich et al., 1975) as an indicator of the state of knowledge of that time (12 years after Flohn's paper was published), only a very limited number of locally confined estimates of the heat transport by the Gulf Stream (some of them estimated during the 1930s) can be found but no comprehensive portrayal. It took more than a quarter of a century after Flohn's work until Broecker (1991) summarized the structure of three-dimensional oceanic circulation and its heat and freshwater transport in terms of a "great conveyor belt circulation". Flohn presents quantitative estimates of the amount of freshwater melting (freezing) during a deglaciation (glaciation). The order of magnitude of the glacier melting rates and the sea level change derived from the mass balance agree with the present-day estimate published by the IPCC (2013). Flohn points to the fact that large quantities of meltwater have to be transported in huge rivers. However, he does not go so far as to speculate what impact these freshwater masses would have on the oceanic circulation since, as mentioned before, little was known about the oceans in 1963. The idea that the amount of freshwater flowing into the North Atlantic ocean could lead to a change in the Gulf Stream circulation emerged about 20 years later after the analyses of sediment and ice cores (Broecker et al., 1985). It was later verified in model studies by Stocker und Wright (1991) and Rahmstorf (1995).

\section{Summary}

In summary, Flohn has compiled the indicators of the climate states during the Pleistocene and interpreted them with his extensive experience in atmospheric circulation. Even though he found contradictions and gaps in the available information, he was able to draw a consistent picture of the atmospheric circulation and its variability during that time period and offered a physically consistent explanation of the sea level change during a glaciation cycle. His main statements are still valid today. After decades of intensive research, one 
can nowadays fill some of the gaps and solve some of the contradictions. Substantial advances have been made in the understanding of the oceanic circulation, its role in the heat and freshwater transport, and its variability. Furthermore, the consideration of multiple feedback mechanisms of a biological, chemical, and physical nature led to an improved understanding of the reaction of the climate system to variations in the external forcings (solar radiation, orbital parameter, volcanic aerosols). Substantial deficits in our knowledge of the climate system still exist, particularly if one considers time periods prior to the Holocene (IPCC, 2013). The tendency to employ "rampant phantasies" to fill these gaps has not disappeared. Even almost 60 years after Flohn's paper and after a substantial increase in knowledge, the scientific community must continue to strive for an improved data coverage and understanding of processes so that the paleoclimate in its entirety can "realistically and physically consistently [be] described using numerical model calculations".

Financial support. The article processing charge was funded by the Quaternary scientific community, as represented by the host institution of EGQSJ, the German Quaternary Association (DEUQUA).

Review statement. This paper was edited by Christine Thiel and reviewed by one anonymous referee.

\section{References}

Berger, A.: Long-term variations of daily insolation and Quarternary climate changes, J. Atmos. Sci., 35, 2362-2367, https://doi.org/10.1175/15200469(1978)035<2362:LTVODI>2.0.CO;2,1978.

Broecker, W. S.: The Great Ocean Conveyor, Oceanography, 4, 79_ 89, https://doi.org/10.5670/OCEANOG.1991.07, 1991.

Broecker, W. S., Peteet, D. M., and Rind, D.: Does the oceanatmosphere system have more than one stable mode of operation?, Nature, 315, 21-26, https://doi.org/10.1038/315021a0, 1985.
Claussen, M., Brovkin, V., Ganopolski, A., Hoelzmann, P., and Pachur, H.-J.: Simulation of an abrupt change in Saharan vegetation in the mid-Holocene, Geophys. Res. Lett., 26, 2037-2040, https://doi.org/10.1029/1999GL900494, 1999.

Dietrich G., Kalle, K., Krauss, W., and Siedler, G.: Allgemeine Meereskunde - Eine Einführung in die Ozeanographie. 3. Neubearbeitete Auflage, Gebrüder Borntraeger, Berlin, Germany, 593 pp., 1975.

Flohn, H.: Zur meteorologischen Interpretation der pleistozänen Klimaschwankungen, E\&G Quaternary Sci. J., 14, 153-160, https://doi.org/10.3285/eg.14.1.17, 1963.

Francis, J. A. and Vavrus, S. J.: Evidence for a wavier jet stream in response to rapid Arctic warming, Environ. Res. Lett., 10, 014005, https://doi.org/10.1088/1748-9326/10/1/014005, 2015.

IPCC: Climate Change 2013 - The Physical Science Basis. Contribution of Working Group I to the Fifth Assessment Report of the Intergovernmental Panel on Climate Change, eidted by: Stocker, T. F., Qin, D., Plattner, G.-K, Tignor, M., Allen, S. K., Boschung, J., Nauels, A., Xia, Y., Bex, V., and Midgley, P.M., Cambridge University Press, Cambridge, UK and New York, NY, USA, https://doi.org/10.1017/CBO9781107415324.005, 2013.

Kaspar, F. and Cubasch, U.: Simulations of the Eemian interglacial and the subsequent glacial inception with a coupled oceanatmosphere general circulation model, in: Development in Quaternary Science 7, The Climate of Past Interglacials, edited by: Sirocko, F., Claussen, M., Sanchez-Goni, M. F., and Litt. T., Elsevier, https://doi.org/10.1016/S1571-0866(07)80058-3, 2007.

Rahmstorf, S.: Bifurcations of the Atlantic thermohaline circulation in response to changes in the hydrological cycle, Nature, 378, 145-149, https://doi.org/10.1038/378145a0, 1995.

Stocker, T. F. and Wright, D. G.: Rapid transitions of the ocean's deep circulation induced by changes in surface water fluxes, Nature, 351, 729-732, https://doi.org/10.1038/351729a0, 1991.

Wanner, H., Beer, J., Crowley, T., Cubasch, U., Flückiger, J., Goosse, H., Grosjean, M., Kaplan, J., Küttel, M., Solomina, O., Stocker, T., Tarasov, P., Wagner, M., and Widmann, M.: Mid to late Holocene climate change - a comprehensive review, Quaternary Sci. Rev., 27, 1791-1828, https://doi.org/10.1016/j.quascirev.2008.06.013, 2008. 